\title{
Tiempos de destape: sexo, cultura y política en la Argentina de los ochenta
}

Valeria Manzano

(UNSAM-CONICET)

\section{Resumen}

El "destape" fue el término con el que se conoció en la Argentina de los tempranos ochenta a la creciente exhibición de, y debate sobre, temas e imágenes considerados prohibidos o difíciles de tratar, que iban desde los ilícitos económicos durante la dictadura hasta la denominada cuestión de los desaparecidos para llegar al recorte que finalmente tomó: el sexo. En tal sentido, el "destape" estaba atravesado por fenómenos transnacionales. En primer lugar, se trató de una actualización de la cultura sexual argentina luego de los años más dramáticos de la censura impuesta por la última dictadura. Esa actualización fue respecto a dinámicas que, iniciadas en la década de 1960, se intensificaron en la siguiente, a saber, la creciente exhibición de (semi) desnudos femeninos en publicidades gráficas y televisivas; la tematización de contenidos sexuales y la incorporación de escenas de sexo explícito en el cine comercial y en teatro; y fundamentalmente la consolidación de la industria de la pornografía que ingresó intensamente en la cultura sexual argentina recién en la década de 1980. En segundo lugar, el "destape" estaba mediado por la interpretación doméstica de los "destapes" en otras sociedades post-autoritarias, notablemente la España post-franquista. De este último caso, se retomó un término-el "destape"-y una serie de categorías que permitían dotar de sentidos a las relaciones entre sexo, cultura y política en un contexto que se entreveía como transicional, o de apertura. 


\section{Keywords}

Unconvering, Culture, Politics, Transition.

\section{Abstract}

The "uncovering" was the term with which in Argentina was known in the early eighties the growing exhibition of, and the debate on, issues and images considered prohibited or difficult to deal with, ranging from economic illicit during the dictatorship to the called issue of "desaparecidos" or missing people, to reach the approach that it finally took: sex. In this sense, the "uncover" was crossed by transnational phenomena. First, it was an update of the Argentine sexual culture after the most dramatic years of censorship imposed by the last dictatorship. That update was related to dynamics that started in the 1960 s, intensified in the following decade, namely, the growing display of (semi) female nudes in graphic and television advertising; the thematization of sexual contents and the incorporation of explicit sex scenes in commercial cinema and theater; and fundamentally the consolidation of the pornography industry that entered the Argentine sexual culture intensely in the 1980s. Second, the "uncovering" was mediated by the domestic interpretation of the "uncovering" in other post-authoritarian societies. , notably post-Franco Spain. From this latter case, a term was resumed - the "uncovering" - and a series of categories that allowed the relationship between sex, culture and politics to be meaningful in a context that was seen as transitional, or open.

El "destape" fue el término con el que se conoció en la Argentina de los tempranos ochenta a la creciente exhibición de, y debate sobre, temas e imágenes considerados prohibidos o difíciles de tratar, que iban desde los ilícitos económicos durante la dictadura hasta la denominada cuestión de los desaparecidos para llegar al recorte que finalmente tomó: el sexo. En tal sentido, el "destape" representó un momento de la puesta en escena del sexo en la cultura de masas que implicó, asimismo, una creciente discusión pública sobre sus relaciones con la cultura y la política. El "destape" estaba atravesado por fenómenos transnacionales. En primer lugar, se trató de una actualización de la cultura sexual argentina luego de los años más dramáticos de la censura impuesta por la última dictadura (1976-1983). Esa actualización fue respecto a dinámicas que, iniciadas en la década de 1960, se intensificaron en la siguiente, a saber, la creciente exhibición de (semi) desnudos femeninos en publicidades gráficas y televisivas; la tematización de contenidos sexuales y la incorporación de escenas de sexo explícito en el cine comercial y -en menor medida-en teatro; y fundamentalmente la consolidación de la industria de la pornografía (D'Emilio y Freedman, 1997: 301-42; Clark, 2008: 198-201; Bronstein y Strub, 2016) que, como se detalla en este artículo, ingresó intensamente en la cultura sexual argentina recién en la década de 1980. En segundo lugar, el "destape" estaba mediado por la interpretación doméstica de los "destapes" en otras sociedades pos-autoritarias, notablemente la España pos-franquista. Expresa o tácitamente, una mayoría de las voces que participaron en los debates públicos y de quienes protagonizaron el "destape" argentino (actrices, actores, directores, productores) se referenciaban en el fenómeno español. De este último, retomaron un término -el "destape"-y una serie de categorías que permitían dotar de sentidos a las relaciones entre sexo, cultura y política en un contexto que se entreveía como transicional, o de apertura.

Además de desplegar un argumento en torno a las dimensiones transnacionales de un fenómeno prácticamente inexplorado, este artículo busca expandir nuestro conocimiento sobre la historia de la sexualidad en la historia argentina reciente. Con su foco puesto en las relaciones entre cultura sexual y cultura de masas en la década de 1980, este artículo dialoga con las investigaciones de historiadoras que se han abocado a períodos anteriores. Así, retoma parte de los hallazgos de esas investigaciones, que han mostrado los modos en los cuales se forjó una creciente erotización de la cultura visual en la década de 1960 -en la publicidad, las revistas de circulación masiva y el cine tanto como en las pautas del vestir de los y las jóvenes- que, más allá 
de los intentos de control y censura, no se discontinuó durante la última dictadura militar cuando, entre otras variables, florecieron las llamadas "sexy-comedias" en el cine argentino (Cosse, 2010; Felitti, 2012; Manzano, 2014; D'Antonio, 2015). Aquí se remarcan las líneas de continuidad en ese proceso de mediano plazo. Sin embargo, también se registra que muchas de las voces que colaboraron a dar sentidos al "destape" identificaron una cesura importante, abonando una hipótesis sobre un efecto de reacción: habría habido tanta represión (sexual y cultural) durante la dictadura, que luego se produjo un "destape". Esa interpretación suponía la creación de una memoria de un pasado por entonces inmediatísimo. Como lo ha destacado la historiadora Dagmar Herzog (2005) en su estudio sobre los vínculos entre memoria y moralidad en Alemania, en la producción de un orden político y cultural durante los tres lustros que siguieron a 1945 una multitud de actores políticos reforzaron la relación entre el Nazismo y la "hiper-sexualidad" a la que habría que poner un freno. De acuerdo a Herzog, fue en el marco de la intelectualidad y la izquierda juvenil de la década de 1960 donde se delineó una interpretación que aunaba en el Nazismo todos los sentidos de "represión" -incluida la sexual-y que permitía dotar a la moral y la cultura sexual de tonos pretendidamente liberadores y/o democráticos. Sin forzar una comparación, esta vertiente interpretativa fue similar a la que se produjo en la Argentina de la primera mitad de la década de 1980: la hipótesis del efecto reacción, en su construcción dicotómica, a la vez opacaba las continuidades en la cultura sexual que habían tenido lugar durante la dictadura y permitía consolidar una imagen de apertura (cultural, política, sexual) que podría tener sus desbordes, como el término "destape" insinuaba.

Esta historia del "destape" es, también, un modo de contar la historia de la transición -una tarea a la que la historiografía se está abocando (Franco, 2017)- y que permite indagar en las posibilidades y disyuntivas del aperturismo cultural promovido por el gobierno de Raúl Alfonsín (1983-1989). Apenas asumido, el nuevo gobierno proclamó la discontinuación de toda forma de censura, y en buena medida así lo fue -como lo demuestra emblemáticamente la derogación de la legislación de censura cinematográfica-. Como lo señalara Roberto Gargarella (2010), como parte de su relato refundacional de la cultura y la política argentina, el alfonsinismo se sostuvo en la restitución del estado de derecho y en la promoción y garantías de las libertades y derechos de "primera generación", incluyendo la libertad de expresión. Sin embargo, mirada la dinámica transicional desde la historia de la sexualidad, esos intentos refundacionales fueron más complicados. Desde distintas instancias gubernamentales, por ejemplo, se autorizó y legitimó la represión de sociabilidades sexuales no heteronormativas (usualmente mediante razzias policiales permanentes en clubes y discotecas que, vale aclarar, florecieron en el contexto transicional) y, como aquí se estudia, se limitó severamente la diseminación de materiales gráficos y circuitos de exhibición de cine que se tildaron de pornográficos. Los funcionarios comprometidos con esas directivas retomaron parte de los reclamos de otros actores fuertes en la disputa "moral" -especialmente, las jerarquías eclesiásticas-y se instalaron, así, como parte de una discusión amplia sobre los límites de la censura y de la acción del Estado en acciones privadas. En términos de políticas, el aperturismo cultural del alfonsinismo encontró rápidamente sus límites cuando se tocó con las dinámicas más extremas de actualización de la cultura sexual, como lo fue la diseminación de materiales tildados de pornográficos. Aquella combinación de aperturismo y límites dio lugar a las conversaciones públicas sobre sexo y política, sobre el "destape", en las cuales fueron cristalizando posiciones y puntos de vista que permiten, a la vez, visualizar que las políticas oficiales retomaban y expresaban a un segmento posiblemente mayoritario de la sociedad argentina de los primeros ochenta.

Basándose en prensa periódica, legislación y otros documentos oficiales y eclesiásticos -y dejando de lado, por cuestiones de espacio, el análisis de filmes, programas 
televisivos y los rastros de las performances teatrales que están analizando otros estudiosos (Garrote, 2013; Lucena y Laboureau, 2016)- este artículo se divide en tres partes, que siguen un orden cronológico y problemático. El primer apartado explora el modo en el cual diversos agentes del campo cultural, a través de la prensa, anticiparon el "destape". Al hacerlo, retomaban interpretaciones del fenómeno español y asociaban sus expectativas y temores en torno a una apertura política y sus relaciones con la sexualidad. El segundo apartado reconstruye esas mismas tensiones en el bienio 1982-1983, cuando se aceleró no solamente la exhibición de materiales domésticos y transnacionales "destapados" sino también el debate público sobre las relaciones entre sexo, cultura y política. Por último, el tercer apartado se centra en las transformaciones del "destape" tras la asunción de Alfonsín. A lo largo de 1984, el "destape" sexual ocupó un lugar de preeminencia, en parte porque se tornaba evidente la puesta al día de la cultura sexual argentina. Frente a esas dinámicas cristalizaron tres posiciones básicas: la conservadora ligada a las jerarquías eclesiásticas (aunque no solo); la "contracultural" que le daba la bienvenida al destape y eventualmente a la pornografía; y una más difusa -posiblemente la más extendida- que era a la vez aperturista y potencialmente limitante.

1. “Dignidad privada”, Esquiú no 874, 23 de enero de $1977,3$.

2. "Editorial: siempre peligroso", Esquiú no 887, 24 de abril de 1977, 10; “Comicios españoles”, Esquiú no 894,12 de junio de 1977 .

\section{Precalentando}

En enero de 1977, el semanario Esquiú-la revista más vendida dentro de la constelación de medios gráficos católicos- publicó un comunicado de un grupo de "padres de familia de España" en el que, en principio, saludaban "el sano aperturismo hacia formas de convivencia social pluralistas" para, acto seguido, condenar lo que describían como "seudoliberacion de los instintos humanos, que produce pingües beneficios a los comerciantes del sexo y la pornografía." Hermanados con los sectores más conservadores de la Iglesia Católica española, los responsables de Esquiú siguieron de cerca la transición en ese país, alarmándose cuando en 1977 se legalizó al Partido Comunista y celebrando que, en las primeras elecciones abiertas, ganase una fuerza "de centro y continuista". Sin embargo, antes que en el "aperturismo" per se, Esquiú se interesaba por sus relaciones con aquella "seudoliberación" que se empezaba a denominar "destape". A través de personas y materiales de prensa, los modos de producir una exhibición y discusión del sexo tanto como el término "destape" viajaron hacia ambos lados del Atlántico. Antes que una prehistoria del "destape" en la Argentina, estos desarrollos transatlánticos fueron clave para la creación de expectativas y temores, y también de un vocabulario con el cual aferrar la conversación sobre los vínculos entre sexo y política.

Acuñado por un periodista de espectáculos tras que, en 1975 se estrenara una película que incluía por primera vez un desnudo femenino frontal, el término "destape" se diseminó rápidamente en la cultura pública española (Ponce, 2004). El desmantelamiento de los mecanismos de censura franquista comenzó en 1977, luego de las primeras elecciones generales en las que resultó elegido presidente de gobierno Adolfo Suárez por la Unión del Centro Democrático. Se trató de un proceso trabajoso, que incluyó la sanción de legislación garantista de la libertad de expresión y de prensa, con el permanente cuestionamiento a la misma (Quaggia, 2014: 105-130). Mientras diversas instancias de gobierno monitoreaban en detalle la difusión de representaciones e información sensible para actores políticos clave de la transición (como las fuerzas de seguridad), fueron más tolerantes respecto al sexo, que pronto se convirtió en la referencia central del "destape". Se intensificó así una dinámica de "sexualización" de la cultura de masas, que incluyó fundamentalmente al cine y a las revistas ilustradas. En la industria cinematográfica, esa sexualización atravesó géneros y estéticas. Desde una perspectiva denuncialista, por ejemplo, cineastas como Eloy 
de la Iglesia tematizaron de manera conjunta la homosexualidad y la transición (en El diputado, estrenada en 1978 en España y recién en 1984 en la Argentina), contribuyendo a delinear una dicotomía que devendría ubicua: al pasado franquista y la represión (política, cultural, sexual) se le oponían las promesas de la democratización. Fueron las comedias, sin embargo, el puntal del "destape", retomando tradiciones de representación marcadamente misóginas y homofóbicas que databan de la década de 1960 y actualizándolas ahora con la mostración de (semi) desnudos femeninos. La saga de películas dirigida por Mariano Ozores, y protagonizada por la dupla de actores de Andrés Pajares y Fernando Esteso fue una de las más representativas de esa línea de "comedias sexy-ibéricas" en el contexto transicional (Monterde, 1993; Cáceres García, 2008). Como en la Argentina lo remarcaba la revista Somos, existía una afinidad evidente entre las temáticas y estéticas de esas películas españolas -que no circularon en el país-con las que por entonces protagonizaba la dupla de Jorge Porcel y Alberto Olmedo. La única diferencia, reconocía el cronista de Somos, es "la tirita que, todavía, cubre un poco a las mujeres argentinas". 3

Mientras la afinidad entre las "comedias sexy-ibéricas" y las "sexy-comedias" argentinas de la segunda mitad de la década de 1970 da cuenta de la dimensión transnacional de ciertos fenómenos de la cultura de masas, no sucedía lo mismo con otro de los baluartes del "destape" español: las revistas ilustradas. La revista Interviú, lanzada en 1976 por el grupo editorial Z, fue señera en ese sentido. Además de "destapar" crímenes e ilícitos económicos del franquismo, Interviú se volvió protagonista de la renovación periodística por incorporar fotos de mujeres semi-desnudas en sus tapas y, en su interior, reportajes gráficos con desnudos completos y crecientemente sexualizados de actrices y modelos famosas, como Sara Montiel o Lola Flores. Otras intervenciones "destapaban" formas de experimentar la sexualidad menos ortodoxas, ofreciendo a los lectores y lectoras crónicas sobre las prácticas del "intercambio de parejas" y la bisexualidad o prestaban creciente atención a la vida cotidiana y la eventual organización política de lesbianas y homosexuales. ${ }^{4}$ Asimismo, las crónicas daban cuenta de la apertura de sex shops y, con un lenguaje coloquial, explicaban los detalles del funcionamiento de los vibradores, asumiendo que se trataba de productos que permitirían, "de una vez por todas, que las españolas sean europeas". ${ }^{5}$ Como sucediera luego en la Argentina en relación con España, el "destape" español también se auto-representó como una forma de actualización de la cultura sexual doméstica vis-a-vis lo que se denominaba "la europea".

Sin embargo, al menos en la prensa gráfica, el proceso de transnacionalización palpable en la cultura de masas y en la cultura sexual española no se agotaba allí: los secretarios de redacción de Interviú, y otras publicaciones eróticas del Grupo Z, como Lib (Carlos Alfieri y Enrique Torres, respectivamente) eran periodistas argentinos exiliados que convocaron a otros colegas que iban llegando en tandas y que incluyeron plumas ya famosas como Horacio Eichelbaum y Mario Mactas. De acuerdo a un ex redactor de Interviú, "los que llegamos de Argentina le aportamos el estilo, los temas, el tono, y los españoles la picardía, la cosa picante...". Como muchos de sus pares, este periodista también retornó a la Argentina en 1983, cuando los "muchachos de Interviu" se diseminaron por las redacciones de revistas muy diversas, desde algunas ya formadas como La semana y Humor, hasta otras que contribuyeron a crear, como El periodista de Buenos Aires. ${ }^{6}$ Aunque aún queda mucho por explorar en este sentido, es posible inferir que buena parte del saber hacer aprendido por esta cohorte de periodistas que experimentaron el "destape" español haya contribuido a modelar algunos aspectos del argentino de los tempranos ochenta o, al menos (como desarrollo más abajo), haya ayudado a consolidar al "modelo" español como una suerte de unidad de medida que permitía indicar cuán lejos y cuán profundo era el proceso argentino.
3. "La hora del mal gusto", Somos, 31 de marzo de $1978,48-54$. Las referencias a los estrenos de películas españolas en la Argentina son tomadas de la base de datos de la Red de Historia de los Medios, construida bajo la dirección del Dr. Fernando Ramírez Llorens: <http://estrenos.rehime.com.ar/>

4. Luis Cantero, "Usted con mi mujer, yo con la suya", Interviú no 50,28 de abril de 1977; Sara de Azcarate, "Lesbianas: las mujeres somos un agujero", Interviú no 58,23 de junio de 1977; J.M. Servia, “Homosexuales contra una ley fascista”, Interviú no 6o, 7 de julio de 1977; Germán Diez, "El swinging ya está aquí". Interviú no 92,16 de febrero de 1978 .

5. J. Sanz y R. Pelleja, "Sex-shop a la española”, Interviú no 82,8 de diciembre de 1977; Raquel Osborne, "Mastúrbate y sé feliz", Interviú no 85 29 de diciembre de 1977; Luis Cantero, "Todo para el sexo, pero sin sexo", Interviú no 94, 2 de marzo de 1978

6. Entrevista con Alberto González Toro, Buenos Aires, 11 de marzo de 2018. 
7. Para estudios sobre aquella apertura del campo cultural, ver Trastoy (1997) y Usubiaga (2012).

8. Alberto Speratti, "Marche una Barcelona vuelta y vuelta", Humor $n^{\circ} 12$, noviembre de 1979, 59-61; "Cuidado, ahí viene un argentino", Humor no 24, septiembre de 1980, 63-65.

9. Carlos Braccamonte, "Aquí destapamos la olla", Humor no 42 , julio de 1980; Guillermo Saccommano, "Lo que las tapas no tapan", Humor $n^{\circ} 54$, marzo de 1981, 46-7.
En la intersección de las décadas de 1970 y 1980, la referencia al "destape" en tanto punto de convergencia de la "apertura" política, cultural y sexual comenzó a impregnar parte de la prensa argentina, desplazándose desde los comentarios sobre el proceso español hacia el escenario local. ${ }^{7}$ En la revista Humor, por ejemplo, un periodista argentino radicado en España enviaba frecuentes crónicas sobre política y vida cotidiana. Una de ellas detallaba, de manera hiperbólica y con comicidad, las vicisitudes de los argentinos que, en Madrid o Barcelona, aspiraban a sostener "sus estrictos códigos sexuales" frente al "destape de hombres, mujeres, perros", poniéndose -de acuerdo al cronista- en "ridículo por mojigatos". En otra crónica ofrecía un balance del "destape" español, comentando que "la parte más chabacana ha quedado atrás" y que, ya en 1979, sus resultados se evidenciaban en una "mayor y mejor oferta pornográfica" $y$, sobre todo, en la posibilidad de que homosexuales y lesbianas vivieran su sexualidad de forma más libre. ${ }^{8}$ Sin embargo, las referencias al proceso español fueron desapareciendo y el término comenzó a utilizarse para referir a lo que, al decir de un periodista, eran "los primeros signos del destape en la Argentina": los (semi) desnudos femeninos en algunas obras de teatro y la mayor visibilidad en quioscos de revistas eróticas, algunas de ellas importadas y otras, como Status, producidas localmente. En el verano de 1981, Guillermo Saccomano retomaba el tema, ofreciendo una interpretación que devendría caballito de batalla en el espacio "progresista": ese "destape" no hacía sino "tapar" problemas como "los despidos y la desocupación", operando como cortina de humo. ${ }^{9}$ Más allá de la lectura sobre los usos y fines de ese "destape", el término pasaba a referir a la Argentina, antes que solamente a España.

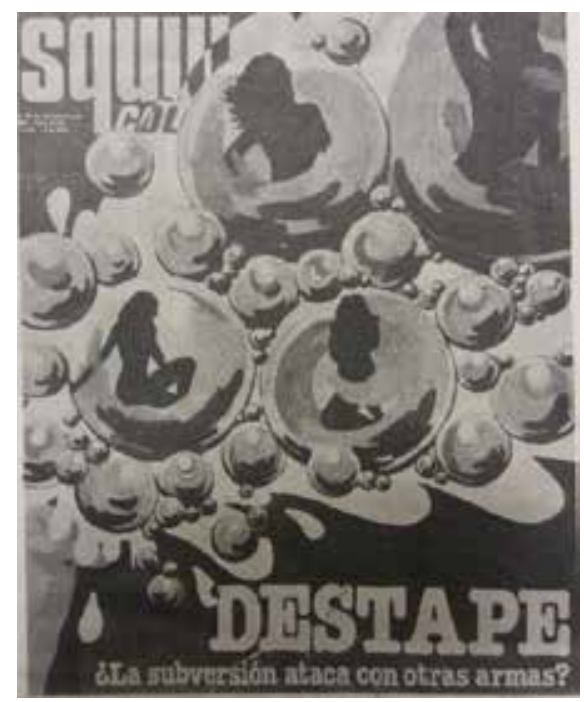

Figura 1

Desde el otro costado del espectro ideológico, los editores de Esquiú no dudaban que ya había un "destape" argentino: "Destape: ¿la subversión ataca con otras armas?", se preguntaban desde la tapa del 6 de diciembre de 1981 (figura 1). Como lo ha señalado el historiador Mariano Fabris (2012), tras la asunción de Viola y la incipiente apertura política, la Conferencia Episcopal Argentina intensificó su permanente campaña de "moralización" de la sociedad argentina, convencidos que aquella apertura implicaría relajar también los controles sobre la esfera cultural y del entretenimiento que, a su criterio, requerían de un monitoreo permanente por parte no solo de la Iglesia (que ya lo hacía a través de sus propias instancias) sino también del Estado. En octubre de 1981, Raúl Primatesta envió una carta al presidente Viola -que los diarios hicieron pública- manifestándole su alarma por "el destape de permisivismo moral y pornografía que invade y corrompe las bases mismas del pudor en las revistas, telenovelas, películas y espectáculos teatrales" ${ }^{10}$ La carta sentaba las coordenadas y el léxico de un tipo de interpretación e intervención que entendía al "destape" como 
"permisivismo moral" que, en palabras de Primatesta "desdibuja notablemente los límites entre lo bueno y lo malo, facilitando una carrera desenfrenada hacia el goce de los sentidos". ${ }^{11}$ Se trataba de una línea argumentativa de larga data: el "permisivismo moral" debilitaba a los más débiles, especialmente los jóvenes, quebrantándoles su fe y su voluntad y tornándolos así presas fáciles para caer en "extremismos" (Manzano, 2015). Al despuntar la década de 1980, a los ojos de la jerarquía eclesiástica y de los responsables de Esquiú-entre otras muchas voces católicas conservadoras-el "destape" ya era una realidad en la Argentina. De hecho, Esquiú le dio la bienvenida a Miguel Paulino Tato como su nuevo periodista de espectáculos. A fines de 1978, Tato había sido desplazado de su puesto al frente del Ente de Calificación Cinematográfica (que ocupaba desde 1974), posiblemente por las presiones de las distribuidoras de filmes norteamericanos que reclamaban, en lo fundamental, por las numerosas calificaciones de "prohibidas para menores de 18 años" a las películas -y se ese modo severamente limitando su audiencia (Ekerman, 2014)-. No casualmente, cuando Tato retomó su tarea periodística, e hizo de Esquiú su trinchera, puso el foco en lo que llamaba "relajo", alarmándose por la "cantidad de películas que se está autorizando a exhibir como aptas para adolescentes, y solo generan depravación". ${ }^{12}$

Aunando sentidos de apertura (política y cultural) y de exhibición y debate del sexo, el término "destape" circuló transatlánticamente en la segunda mitad de la década de 1970 y, para 1981, de acuerdo a distintas voces -y no solo las más alarmistas ligadas a la Iglesia Católica- ya había signos de su anclaje en la Argentina. Aunque por motivos diversos, la recepción y los comentarios iniciales sobre el "destape" fueron negativos, ya sea que, de modo exacerbado, el énfasis se pusiera en el peligro o el "permisivismo" moral; o en la "chabacanería" que suponía para la cultura de masas; o bien en su capacidad de "tapar" problemas que se consideraban más urgentes. En el bienio que siguió, cuando -más allá de las incertidumbres- una apertura política se percibía a la orden del día, esos argumentos cuestionadores del "destape" fueron reformulados por un arco cada vez más amplio de voces, que también mirarían al ejemplo español para debatir qué hacer con la censura y de qué manera imaginar vínculos entre el estado y la sociedad.

\section{¿Un destape a la argentina?}

En los intensos meses que mediaron entre julio de 1982 (tras el anuncio del fin de la veda política) y la asunción de Raúl Alfonsín en diciembre de 1983, la percepción de estar experimentando un "destape" comenzó a ganar mayor pregnancia en la cultura pública. De acuerdo a un cronista de Clarín Revista, para fines de 1982 los signos de ese "destape" ("nada parecido a lo que ocurriera tras la muerte de Franco", agregaba) incluían, sobre todo, el relajamiento de la censura respecto a artistas y materiales previamente prohibidos. ${ }^{13}$ Durante aquel lapso temporal, en efecto, la transformación en los modos de mostrar el sexo fue muy limitada. Aún así, esa transformación sirvió como plataforma para el recrudecimiento de los debates públicos sobre los potenciales alcances y significados del "destape a la argentina", que canalizaban los temores y las expectativas en torno a qué harían -si algo harían- las autoridades electas por el voto popular respecto al mismo. Como parte del proceso, el "destape" español siguió funcionando como unidad de referencia, mucho más cuando parte de quienes modelaban al emergente fenómeno argentino (periodistas, actrices, productores) también retornaban al país y reactualizaban sus impresiones y experiencias.

Durante la temporada de verano 1982-1983, algunos episodios de la cultura de masas encendieron las luces de alerta sobre la aceleración del "destape" argentino. Uno de
11. Una carta al presidente", Clarín, 19 de octubre de 1981, 17.

12. Néstor, "Esto sí, esto no", Esquiú $\mathrm{n}^{\circ}-1118,27$ de septiembre de 1981; Néstor, "Moral y TV", Esquiú nำ1119, 4 de octubre de 1981.

13. Alejandro Margullis, “Un destape a la argentina", Clarín Revista, 21 de noviembre de $1982,4^{-5}$ 
14. "Las trampas de la publicidad erótica" Tiempo Argentino, 12 de diciembre de 1982, segunda sección, 2-3.

15. "La censura hizo voto de clausura", Gente №. 917,17 de febrero de 1983 .

16. “Adrián Ghío procesado", Clarín, 27 de mayo de 1983, 19.

17, Ver, para esas posiciones, "Los actores frente a la censura", Clarín 30 de mayo de 1983.21 ¿Quién entiende esta clausura?", Gente no 931, 25 de mayo de 1983; “Configura delito de obscenidad Doña Flor y sus dos maridos?", Esquiú $\mathrm{n}^{0} \mathbf{1 2 0 6 , 5}$ de junio de 1983.

18. El documento completo está disponible en <http://www.episcopado.org/DOCUMENTOS/12//198215Moralidad_66.htm> (última consulta el 15 de mayo de 2018). 19. "Una vigorosa denuncia episcopal", Esquiú no 1185, 9 de enero de 1983.

20. "La pornocracia quiere avasallar todo lo que hay de noble en este pueblo", Esquiu $\mathrm{n}^{\mathrm{0}}$ 1201, 1 de mayo de 1983 . los primeros episodios fue la exhibición y rápida censura de una publicidad televisiva. El corto publicitario, a cargo de la firma Radvic, enfocaba traseros femeninos en bikini y lanzaba el slogan "Hitachi, qué bien se te ve". Tras solo un día en el aire, el Comité Federal de Radiodifusión lo prohibió, desatando así un debate entre agentes publicitarios. Los representantes de las agencias Rowland y Dreyfus, por ejemplo, no cuestionaron la censura y señalaron, en cambio, que se trataba del ejemplo más extremo de los "comerciales del destape"-aludiendo a todos aquellos que incluyeran mujeres en bikini, o en poses sensuales- que, a su criterio, proliferarían porque era "natural, después de tanta prohibición". Como otras voces del mundo del entretenimiento, ellos recurrían a una explicación por reacción (hubo tanta prohibición, que la respuesta era la inversa) y añadían una preocupación sobre cómo cuidarse para que "no se nos vaya la mano", un temor al exceso que, en esos temas, según ellos, rozaría en la "chabacanería". ${ }^{14} \mathrm{El}$ siguiente episodio fue más resonante aún, en parte porque el argumento de la "chabacanería" -que, como detallo más abajo, servía para legitimar limitaciones y censuras- no pudo utilizarse. Se trató de una acción conjunta de la División Moralidad de la Policía Federal y el Departamento de Clausuras de la Municipalidad de Buenos Aires, que a principios de febrero de 1983 clausuraron la sala teatral donde se representaba Doña Flory sus dos maridos (basada en la novela de Jorge Amado), una obra calificada como prohibida para menores de 18 años por su temática (donde se narraba el adulterio y la fantasía sexual) y porque había escenas con desnudos frontales femeninos $y$ masculino. ${ }^{15}$ Durante el primer semestre de 1983 siguió el curso judicial, que terminó en el procesamiento de los actores (Adrián Ghío y Ana María Cores), del director y del productor de la obra por presunta obscenidad. ${ }^{16}$ La decisión judicial partió las aguas y potenció el debate público en torno a las relaciones entre sexo, cultura y política en el marco del inminente proceso eleccionario: mientras que un grupo de actores, directores y productores teatrales se movilizaron, parte de la prensa se interrogó por la arbitrariedad de la decisión y las voces más conservadoras de la Iglesia Católica aplaudieron a policías, emisarios municipales y jueces. ${ }^{17}$

Si desde mucho tiempo atrás las jerarquías eclesiásticas venían configurando una posición alarmista frente al "destape", la apertura política y lo que concebían como una "avalancha de permisivismo" las llevó a delinear posiciones cada vez más extremas y militantes. A fines de 1982, la Comisión Episcopal para los Medios de Comunicación Social (integrada por los obispos Héctor Romero, Vicente Zazpe y Oscar Villena) dio a conocer un comunicado en el cual denunciaban la corriente "de violencia y sexualismo" que, a su criterio, ya no se quedaba "aislada en las salas de espectáculos, sino que penetra en la intimidad doméstica a través de la televisión; salta a la calle desde las revistas y las carteleras y tiende inclusive a una total expansión". ${ }^{18}$ En el centro la atención episcopal estaba la libertad de expresión: ante las posibilidades de extenderla, los obispos y las voces católicas más conservadoras asumirían la defensa del "derecho al pudor", y de las supuestas libertades individuales y colectivas avasalladas por la "oleada pornográfica". ${ }^{19}$ Las voces más reaccionarias, como la del obispo Héctor Romero (de Lomas de Zamora), definían con un neologismo a lo que percibían como una doble amenaza: la "pornocracia", esto es, la democracia que instauraría - de no mediar los límites que la Iglesia Católica buscaría imponer- un nuevo status quo donde "se mezclarían drogas, prostitución, pornografía", y el "destape" español nuevamente venía al auxilio cuando buscaban ejemplificar de qué se trataba esa "Sodoma y Gomorra". ${ }^{20}$

El temor y la denuncia de una inminente "pornocracia" constituyeron una posición minoritaria dentro de las voces que reaccionaban frente al "destape": entre quienes se pronunciaron públicamente se conjugaron versiones más moderadas sobre los límites de la libertad de expresión en relación con la exhibición más abierta del sexo. El diario Tiempo Argentino -que desde su lanzamiento a fines de 1982 se proponía 
atender a un segmento de lectores urbanos y de los sectores medios, alineándose con el radicalismo- publicó al menos dos docenas de cartas de lectores en torno al "destape". El puntapié inicial lo dio una lectora de 36 años, quien reaccionaba frente a la tapa y el contenido de una revista de puericultura (Vivir), en la cual se mostraba a una familia desnuda. A la vez que cuestionaba el "naturalismo extranjerizante" de esa tapa, la lectora sostenía que su carta "no fuera utilizada como justificación para los censores, sino como llamado de alerta a los que quieren vender a cualquier costo". Las respuestas no tardaron en llegar: mientras una lectora escribió para apoyar "en todo", otro le discutió el tema de cuán extranjerizante era el "naturalismo" y un tercero le cuestionó el "oscurantismo que, en definitiva, reclama la censura" pero que, a su criterio, se enfocaba en un mal ejemplo sin mencionar materiales mucho más "chabacanos". ${ }^{21}$ Otra lectora afirmaba que creía "en la democracia y en la libertad de prensa, pero creo también que esa libertad no pasa por esta oleada de desnudos de mal gusto". ${ }^{22}$ La cadena de significados en torno al "mal gusto", la "chabacanería" y la "pornografía" se anudaba también con la de la comercialización de lo sexual, o las referencias al "sexo para vender". Estos lectores (y otros que escribieron a diarios más tradicionales, como La Nación ${ }^{23}$ ) identificaban en esa cadena los límites negativos del "destape" y dudaban sobre cuánto extender la libertad de expresión.

Sin embargo, con el transcurrir del año electoral, diferentes voces se fueron animando a reclamar el fin de la censura para toda forma expresiva -y aquí, nuevamente, el ejemplo español fue clave-. Desde el corazón mismo de la industria del espectáculo, productores y artistas tildados usualmente de "chabacanos", al ser consultados, defendieron públicamente lo que concebían como un "derecho de la democracia". Así, por ejemplo, Gerardo Sofovich -cuyos ciclos televisivos eran, para muchos, el ejemplo básico del mal gusto, amén de la homofobia y el machismo-comentaba que mientras "mucha gente del ambiente intelectualizada se llena la boca contra la censura, pide que se censuren mis programas". A la inversa, él proponía el levantamiento de todo tipo de censura y se animaba a la comparación con España donde, en su opinión, "se llegó a una madurez política destacable y no reprimieron" sino que "toleraron los excesos hasta que se calmó". ${ }^{24}$ La vedette Moria Casán, quien aseguraba haber pasado una temporada larga en Madrid, era de la misma opinión: "el destape español no tuvo ninguna restricción", sostenía, hasta que "la cosa se normalizó", algo que creía debía darse también en la Argentina. ${ }^{25}$ El director de cine Mario Sábato, mientras tanto, despotricaba contra la pornografía "porque ofende a las personas en cuanto tales" pero, sostenía, "las personas pueden hacer con su alma y su conciencia lo que quieren". La confianza en la libertad individual para decidir, sin que medie la imposición estatal, era también defendida por quienes estaban más comprometidos con el "destape". Así, el director de Don-una revista para Juan se manifestó por el "derecho al placer" y auguró que el "furor pornográfico" no duraría, con lo que coincidía Miguel Brascó, director de Status. ${ }^{26}$

Desde mediados de 1983, programas televisivos y revistas ilustradas representaban el "destape". Aunque todas se dirigían a un público masculino, las revistas "del destape” eran muy variadas: mientras las más longevas, Status o Don, no solamente eran más caras sino que mantenían alguna pretensión de filiarse estéticamente con publicaciones al estilo de Playboy, la mayoría eran semanarios tipo tabloide, con una composición simple y la atención centrada en las fotografías de mujeres semi desnudas en las tapas y en los reportajes gráficos interiores. Destape, Shock, Viva, El testigo del destape o Climax competían por incluir fotografías y reportajes "picantes" a las vedettes de televisión usualmente relacionados con sus preferencias en torno a parejas, posiciones sexuales o fetiches. Esas "musas del destape" local incluían a Noemí Alan, Amalia "Yuyito" González, Luisa Alberoni, Silvia Peyrou, Lía Cruzet o Carmen Barbieri, entre otras menos conocidas (figura 2). ${ }^{27}$ Aunque todas las revistas exhibían un cartel de prohibidas para menores de 18 años, a fines de 1983 la prensa registraba que su
21. "Cartas de lectores: Cuando del destape se vuelve aberrante", Tiempo Argentino, 2 de junio de 1983 , 23; "Cartas de lectores: Más sobre el destape", Tiempo Argentino, 8 de junio de 1983, 23; "Cartas de lectores: Oscurantismo y destape", Tiempo argentino, 13 de junio de 1983, 15; "Cartas de lectores: Punto de vista", Tiempo Argentino, 14 de junio de 83, 23.

22. "Cartas de lectores: Destape y censura", Tiempo Argentino, 22 de septiembre de 1983, 23; "Cartas de lectores: El falso destape", Tiempo Argentino, 22 de noviembre de 1983, 23.

23. Ver, por ejemplo, "Cartas de lectores: pornografía”, La Nación, 8 de noviembre de 1983; "Cartas de lectores: Exhibicionismo", $\mathrm{La}$ Nación, 14 de noviembre de 1983.

24. "El destape, el mal gusto y yo", Gente nº 948,22 de septiembre de 1983.

25. "La única que sabe del destape soy yo", Gente no 949 , 29 de septiembre de 1983.

26. “Destape, ¿sí o no? Pornografía, ¿sí o no?”, La semana ํㅜ 363 24 de noviembre de 1983 .

27. Ninguna biblioteca pública ha conservado colecciones de esas revistas. Algunos números de Climax pueden consultarse en la Biblioteca Nacional, y otros están disponibles para la compra en sitios online. Mi descripción está basada en 40 ejemplares de títulos diversos que cubren desde mayo de 1983 hasta julio de 1984. Para una descripción crítica del contenido de las mismas, ver Jorge Capiski, "Por fa作 $\mathrm{n} \cong 34$, diciembre de $1983,45-50$. 
28. "Venta en los quioscos", Clarín, 30 de noviembre de 1983, 35 .
29. "Expresiones de condena por la ola de pornografía”, La Nación, 18 de noviembre de 1983; ver también "Advertencias del Doctor Tróccoli", La Nación, 27 de noviembre de 1983, 1. 30. "Editorial: libertad de prensa y pornografía”, La Nación, 29 de noviembre de 1983, 8. "Esperemos que así sea", Esquiú no 1231 27 de noviembre de 1983 . 31. Osvaldo Soriano, "La autocensura de la democracia”, Humor no-118, diciembre de 1983, 28-9.

32. "Accionan contra la pornografía", Tiempo Argentino, 29 de noviembre de 1983, 16; "Controlan la exhibición de las revistas del destape", Clarín, 30 de noviembre de $1983,35-6$.

33. Raúl Alfonsín, “Mensaje del Sr. Presidente de la Nación a la Honorable Asamblea Legislativa, 10 de diciembre de 1983", en 10 de diciembre de 1983 ", en
Discursos presidenciales (Buenos Discursos presidenciales (Buenos
Aires: Secretaría de Prensa de la Presidencia de la Nación, 1984), 9.

34. "Régimen de calificación de elículas cinematográficas”, Boletín Oficial, 21 de marzo de 1984, 5 . venta era libre. Para la alarma de aquellas voces que reclamaban restricciones, una mini encuesta entre vendedores de diarios y revistas arrojaba la imagen de los compradores más habituales: "varones de todas las edades, pero principalmente adolescentes". ${ }^{28}$ Y muchos más se hacían con ejemplares de revistas más establecidas -Gente, Siete Dias, o La Semana - que en esos meses también, de modo creciente, sexualizaban sus tapas y contenidos.

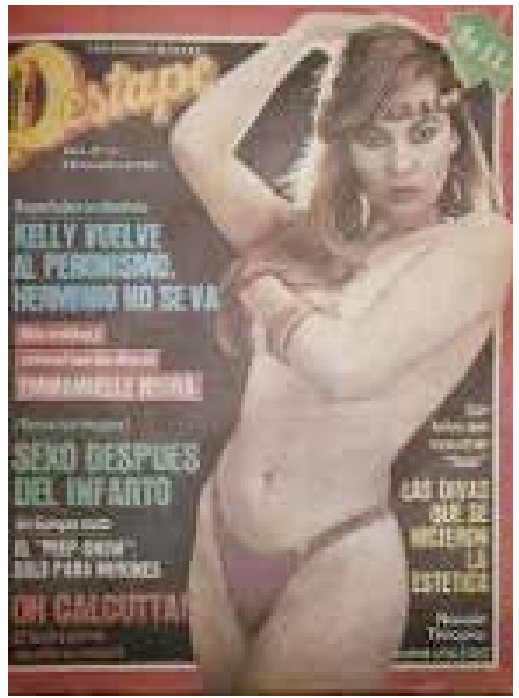

Figura 2.

El cambio de gobierno potenció la discusión pública sobre el "destape". Al poco de conocerse su designación como futuro Ministro del Interior, Antonio Tróccoli se refirió al tema: "detrás del destape y la pornografía está la mafia con su negocio", sentenció, para luego afirmar que el nuevo gobierno buscaría "llevar el libertinaje ante la justicia". ${ }^{29}$ Las declaraciones levantaron revuelo. Desde las esquinas más conservadoras, La Nación y la prensa católica saludaron esa "actitud enérgica", mientras que la Liga de la Decencia de Rosario y las Ligas de Madres y Padres de Familia le ofrecieron su apoyo al Ministro..$^{30}$ Desde otras vertientes del espectro de opiniones, mientras tanto, se encendían las luces de alerta sobre los límites que se iba imponiendo el radicalismo. Osvaldo Soriano, por ejemplo, escribía que esa decisión "autocensura a la democracia". ${ }^{31}$ Aunque fue leído de otra manera, el Ministro Tróccoli se había cuidado de no mencionar la palabra "censura" y de reforzar, en cambio, la idea de judicializar los procedimientos contra eso que nadie podía definir: la pornografía. En esa línea, poco antes de la asunción de Alfonsín, previo acuerdo con las autoridades salientes, comenzó una intensa y muy promocionada campaña que apuntaba a que las revistas del "destape" no fueran exhibidas en la vía pública bajo amenaza de aplicar el famoso artículo 128 del código penal (que prohíbe la diseminación de materiales obscenos) a quienes así lo hicieran. ${ }^{32}$

Apenas lanzado, el gobierno radical mostraba ambivalencias respecto a las relaciones entre sexo, cultura y política anudadas en el término "destape". Por un lado, ya desde su mensaje de apertura de la Asamblea Legislativa, el 10 de diciembre de 1983, Alfonsín anunciaba que "termina hoy el triste tutelaje sobre los habitantes de este país", llamando al "restablecimiento de las libertades públicas". ${ }^{33}$ En ese mismo sentido iba la sanción de la Ley 23.052, promulgada el 3 de marzo de 1984, por la cual se derogaba la Ley 18.019 que, sancionada en 1968, había servido como marco general para el desarrollo de mecanismos de censura cinematográfica. La nueva ley establecía la creación de una Comisión Asesora de Calificación, cuyas decisiones gravitarían en la Ciudad de Buenos Aires y territorios nacionales, cuyos fines principales eran determinar qué películas podían ser vistas por menores de edad y establecer "calificaciones" para las películas que podrían ver los adultos. ${ }^{34}$ Tanto muchos contemporáneos como 
comentaristas actuales coinciden en que aquel mensaje y esta ley, en particular, mostraban la voluntad política del primer tramo del gobierno radical para privilegiar los derechos "de primera generación" y para trazar, en el terreno cultural, una "frontera política" con el pasado recentísimo, oponiendo autoritarismo a democracia (Aboy Carlés, 2001: 199-210; Gargarella, 2010).

El reconocimiento de la voluntad política que impregnó al relato refundacional que pretendía el alfonsinismo se complica al ponderar la política de corte represivo respecto a la práctica de sexualidades no heteronormativas y a las manifestaciones del "destape". Como lo vienen desarrollando una serie de trabajos, durante los primeros meses del gobierno de Alfonsín se recrudecieron las razzias policiales a espacios de sociabilidad de homosexuales y lesbianas, contexto en el cual se dio la creación de la Comunidad Homosexual Argentina (Sempol, 2013; Blazquez y Lugones, 2014; López Perea, 2017). Los límites que se fueron estableciendo respecto a la diseminación de aquello que las voces oficiales tildaban de "pornografía" o "libertinaje" iban en el mismo sentido. En esa dinámica, al menos algunos segmentos del alfonsinismo -en particular, los más cercanos al Ministro Tróccoli- se filiaban con una tradición de mediano plazo en el radicalismo que, a partir de una afinidad con sectores de la Iglesia Católica, habían solidificado un discurso centrado en la defensa de la familia y la moral y puesto en práctica políticas de control de las sexualidades no normativas, como sucedió durante la amplísima "campaña de moralización" emprendida en 1959 y 1960, durante la presidencia de Arturo Frondizi (Manzano, 2005). Sin haberse llevado a cabo una campaña de tal magnitud y en un momento cualitativamente diferente en la historia de la cultura sexual argentina, durante el primer tramo del alfonsinismo el gobierno osciló entre iniciativas aperturistas y políticas represivas vis-a-vis modos de mostrar y de experimentar el sexo que no se consideraran "convencionales".

\section{El destape que (se) tapa}

A fines de 1983, la periodista feminista Nelly Casas escribía: "no hemos descubierto ahora que el destape puede ser un poderoso impulsor de ventas (...) un extremo del movimiento pendular de sociedades reprimidas". Sin embargo, sí encontraba elementos nuevos: "lo que nos descubrimos pensando ahora es hasta qué punto nos aguantamos el tremendo peso de la libertad (...) hasta dónde podemos permitir el ejercicio de nuestro derecho en ese sentido sin jugar nuestro temor a parecer censores". Se trataba de un "nosotros" que no representaba a las posiciones más conservadoras - para quienes todo se resolvía con reclamar controles que evitaran el "permisivismo"- sino a otras que genéricamente se podrían definir como progresistas. Esas posiciones marcaban la relación entre "destape" y comercialismo, el vínculo que veían como intrínseco entre represión y destape y, también, los temores que podía despertar en ese "nosotros" el descubrirse fantaseando con censurar. A todo esto se añadían dos elementos interrelacionados. Por un lado, tanto Casas como otros comentadores de esas voces progresistas -incluyendo a Sandra Russo, Jorge Rivera, Oscar Landi y José Ricardo Eliaschev- indicaban que el "destape" no significaba libertad, sino todo lo contrario, porque suponía la "exacerbación del machismo y la cosificación de las mujeres". Por otro lado, Casas sintetizaba una noción que devino una suerte de letanía, "el destape tapa", esto es, el "destape" era una cortina de humo para oscurecer "problemas de fondo". ${ }^{35}$ En su conjunto, desde esas voces más intelectualizadas no se leyó al "destape" en sus propios términos, sino antes bien se lo delineó como un problema que oscurecía otros problemas (políticos, de género). De modo más general, sin embargo, esa posición a la vez aperturista y potencialmente limitante se diseminó más acabadamente en el conjunto del entramado social, y algunas encuestas la muestran como la posición mayoritaria. Tras discutir brevemente cómo se situaba
35. Nelly Casas, “¿Qué tapa el destape?”, Tiempo Argentino, 26 de noviembre de 1983, Suplemento "Mujer", 3. Los entrecomillados del párrafo son de esta nota. Las otras referencias son, Sandra Russo, "País con la faja qun, Sandra Russo, "País con la faja 1983, 9; Jorge Rivera, "Qué hay detrás del destape" y Oscar Landi, "Así no se trata a una dama", Clarín, 1 de marzo de 1984, Suplemento "Cultura y Nación", 2-3; José Ricardo Eliaschev, "El destape deja la tapa intacta", Superhumor $\mathrm{n}^{0}$ 37, marzo de 1984 . 
36. Jorge Halperín, “¿De quién es ese cuerpito?”, Clarín, 23 de diciembre de 1983, 15 .

37. "La tortura como pornografía", Alfonsina $\mathrm{n}^{\circ} \mathrm{4}, 23$ de enero de 1984, 3 .

38. Enrique Torres, “¿Destape? Seamos serios", La semana $\mathrm{n}^{\circ} 363$ 24 de noviembre de 1983, 39 .

39. "Revistas del destape, solo en quioscos cerrados", Clarín, 29 de diciembre de 1983, 28.

40. "Integrarán una comisión", Clarín, 28 de febrero de 1984, 29. el "destape sexual" en una dinámica más general de "destape" informativo en el caldeado verano de 1984 en este segmento me detendré en autonomizar solo dos de las avenidas en las cuales cultura de masas y cultura sexual se intersectaron: la discusión sobre, y judicialización de, las revistas eróticas y pornográficas; y las consideraciones sobre la posibilidad de exhibir películas "condicionadas". Fue a partir de esas dinámicas que fueron tomando estado público una posición minoritaria, que en aras de brevedad referiré como "contracultural" y aquella otra, mayoritaria, que sintonizaba bien con el aperturismo y el limitacionismo de las políticas oficiales.

El pico de la preocupación por el "destape" sexual coincidió temporalmente con el "destape" de los relatos sobre la represión ilegal durante la última dictadura, -conocidos como el "show del horror" -y, en este punto, la diferencia con el caso español es notoria, ya que la prensa de la transición en aquel país no abordó los asesinatos ni las fosas comunes del franquismo (como sí, intensamente en el caso de Interviú, tematizó la represión franquista en los ámbitos educativos y culturales, o los casos de corrupción y delitos económicos). Como lo ha mostrado Claudia Feld (2015), el "show del horror" en la prensa argentina fue montándose en función de ideas en torno a "hallazgos" y "descubrimientos" de fosas con cuerpos sin identificar para explotar, en los meses que siguieron a la asunción de Alfonsín (al mismo tiempo en que se iniciaban las investigaciones de la CONADEP) en una sucesión de tapas y notas centrales en las principales revistas ilustradas que intentaban reproducir los mecanismos de secuestro, tortura y desaparición de personas. Con tono amarillista, buena parte de la prensa gráfica que hasta meses antes se había alineado con el régimen militar asumía un tono pretendidamente "denuncialista" mediante el cual, no obstante, se le otorgaba voz y credibilidad a represores de distinto rango, no se ofrecían "mediaciones" que lograran dar sentido y explicación a lo relatado y -concluye Feld-terminaba por naturalizarse el horror y "deshumanizarse" a las víctimas (que no recibían ese nombre, sino el otorgado por los perpetradores). Como lo comentaron algunos periodistas en su momento, las mismas publicaciones, como Gente, Perfil, Libre o La semana, eran vehículos de ambos "destapes" -el del "show del horror" y el sexual- en los que los cuerpos estaban en el centro de la escena. Se mostraban a la vez "cuerpos voluptuosamente hinchados por cirugías estéticas", escribía Jorge Halperín, y "cuerpos estallados en mil pedazos, o hechos desaparecer", todos en un mismo plano, incluso en una misma tapa. ${ }^{36}$ Una editorial de la revista feminista Alfonsina iba un paso más allá al apuntarle al efecto de la repetición y de la ausencia de un relato (por ende, de una interpretación y un sentido) que, a su criterio, se replicaba en "el show de los desaparecidos" y el "de las nalgas descubiertas". ${ }^{37}$ Ética y políticamente problemáticos, estos "destapes" se sustentaban en la comodificación de esos relatos e imágenes. El éxito de ventas de algunas publicaciones se basaba en la combinación de sexo y denuncialismo. Periodistas como Enrique Torres (a cargo de las publicaciones eróticas del grupo $\mathrm{Z}$ en Barcelona) lo habían aprendido bien, y al retornar a la Argentina trajeron ese saber hacer en su procura de renovar el mercado de revistas doméstico apuntando al escándalo. ${ }^{38}$

Mientras se producían esos "destapes", se intensificaba la batalla en torno a los materiales impresos, particularmente las revistas del "destape" propiamente dichas. La Secretaría de Cultura de la Ciudad de Buenos Aires, a cargo de Pacho O'Donnell, creó una nueva comisión para la calificación de materiales impresos. A fines de diciembre de 1983, la comisión calificó como de "exhibición limitada" a varias de las revistas del "destape", incluyendo Climax, El guardián del destape y Viva, que solo podrían ser exhibidas en locales cerrados. ${ }^{39}$ "Hay gente que parece no entender la diferencia entre libertad y suciedad mental", dijo O'Donnell al justificar públicamente lo que concebía como una necesidad urgente de "defender a la minoridad de la pornografía" mediante, seguía, el "establecimiento de nuevas reglas". ${ }^{40}$ Esas reglas nunca se explicitaron, sino que los posicionamientos públicos de las autoridades políticas sentaron las 
condiciones para una andanada de judicialización. Como ya había sucedido en la década de 1960 (Eidelman, 2015), algunos abogados representantes de grupos católicos, como Javier Vergara y Fernando Soaje, estuvieron a la vanguardia de las denuncias judiciales por presunta violación del artículo 128 del Código Penal a numerosas revistas del "destape" o a aquellas que publicaran desnudos en sus tapas o reportajes gráficos con desnudos en sus interiores, como en el caso de Libre. Mientras tanto, el juez Roberto Calandra, quien recibió las felicitaciones públicas de la Comisión Episcopal Argentina por ello, dio lugar a decomisos y a numerosos procesamientos de editores y distribuidores. ${ }^{41}$ Así, tras el corto verano de 1984 en el cual el "destape" había implicado, en lo fundamental, la ubicuidad de los desnudos y semi desnudos (como lo remarca la viñeta de Góngora, aparecida en Humor en enero de 1984 -ver figura 3-) muchas publicaciones comenzaron a discontinuarse, en muchos casos obedeciendo no necesariamente a la falta de demanda sino a las dificultades financieras que los procesos judiciales (y las amenazas de judicialización) acarreaban para sus productores y distribuidores.

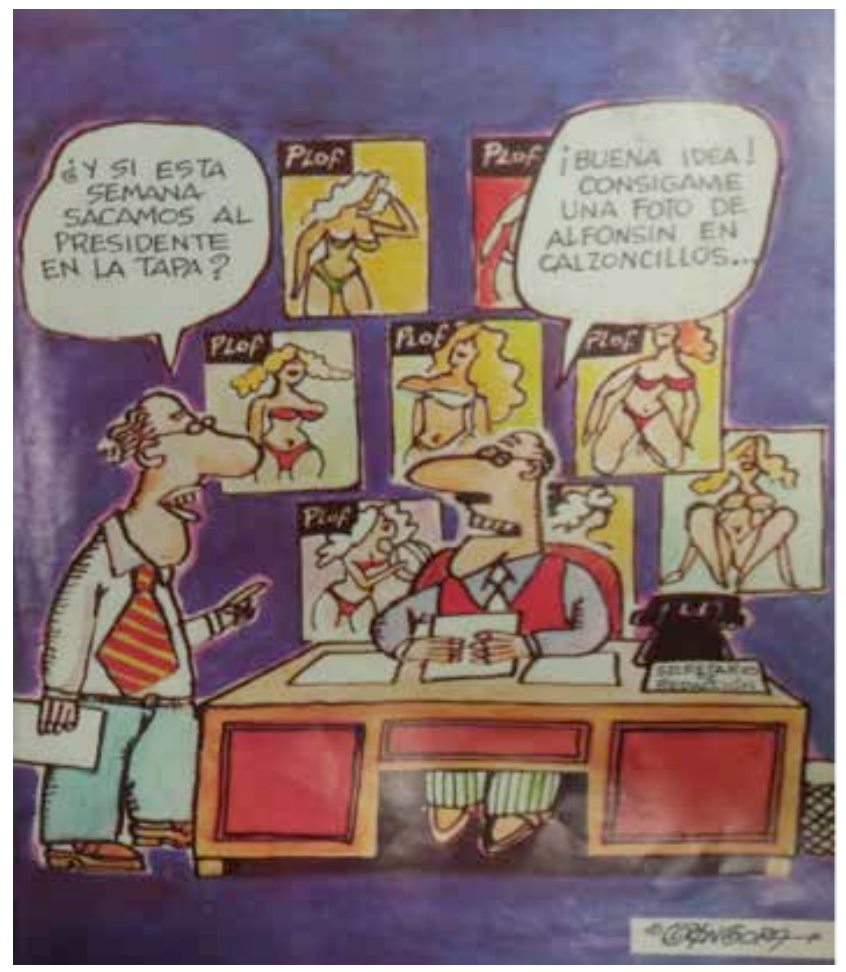

Frente a la intensificación de los procesos judiciales (y frente a las razzias que se sucedían en paralelo) solo se alzaron vivamente algunas voces del mundo periodístico e intelectual, que sintéticamente podrían definirse como "contraculturales". El periodista y organizador contracultural Enrique Symns, en particular, muy tempranamente sostuvo que el gobierno radical era "profundamente antierótico". Symns se interesaba en desmontar las argumentaciones de Pacho O'Donnell, quien pretendía hacer uso de su saber psicoanalítico para legitimar los cercenamientos de la libertad de expresión. Así, Symns retomaba una cita del Secretario de Cultura -"hay razones éticas, morales religiosas y psicológicas que hacen al control de la pornografía"- para rebatirla sosteniendo, por un lado, que "en la Argentina no hay pornografía" y, por otro, que esta era "necesaria" porque, a su criterio, "excita los rincones polvorientos de nuestro deseo". ${ }^{42}$ Sin coincidir con esa visión complaciente de la pornografía, muchos de quienes colaboraron con Alfonsina reconocían que los límites que el oficialismo les estaba intentando imponer configuraban una política sexual conservadora. En ese
41. "Ofensiva judicial por presunta obscenidad”, Tiempo Argentino, 24 de marzo de 1984, 17; "Más procesos a revistas destapadas", Tiempo Argentino, 6 de abril 1984, 15; "Denuncias en justicia por la pornografía", Clarín, 17 de abril de 1984, 27.
42. Enrique Symns, “El radicalismo y la cruzada antierótica", El porteño $\mathrm{n}^{0} 28$, abril de $1984,22$. 
43."La madre de todas nosotras", Alfonsina $\mathrm{n}^{\circ}{ }_{1,15}$ de diciembre de 1983, 4-5; Ana María Amado, "Ataquemos al porno, pero e "Arno dónde está?" Alfonsina no 6, 23 de febrero de 1984, 18 .

44. "Las argentinas y la pornografía", Tiempo Argentino, 17 de diciembre de 1983 , Suplemento “Mujer”, 4.

45. "Esto piensan los argentinos del destape y la censura", Gente no 969,16 de febrero de 1984 .

46. Heriberto Muraro "La deología sexual de los porteños", Clarín, 1 de marzo de 1984, Suplemento Cultura y Nación, 3 .

47. "La moral media de los argentinos", El porteño n 33, septiembre de 1984 .

48. “ ¿Es usted el jefe de la patota cultural?", Gente no 970, 23 de febrero de 1984; " "Replicó Monseñor Di Stefano juicios de un funcionario", Tiempo Argentino, 24 de marzo de 1984, 9. sentido iban, por ejemplo, María Elena Walsh, quien en una entrevista planteaba que "la pornografía es cosa de hombres" pero que, en aras de sostener la libertad, "no debemos tolerar ninguna censura o persecución"; y también Ana Amado, quien sostenía que "al porno hay que atacarlo por motivos éticos y estéticos, pero dejarlo venir". ${ }^{43}$ Más anónimas, también otras voces sostenían que "te guste o no", habría que "dejar que venga el porno", como lo sintetizaba una empleada de 56 años, mientras una publicista de 43 agregaba que, incluso, "ayudaría a liberar las fantasías".44

Las pocas encuestas longitudinales que trataron el tema, mientras tanto, mostraban posiciones menos entusiastas respecto al "destape", pero no por ello conservadoras: la más extendida era una posición intermedia, que ponía en el centro a la libertad de expresión tanto como las transformaciones en la moral sexual. A principios de 1984, una encuesta en el área metropolitana de Buenos Aires realizada por la firma A\&C interrogaba a 450 personas sobre sus opiniones no sobre la pornografía sino sobre el "destape": un 50 por ciento de los varones y un 48 por ciento de las mujeres entre 18 y 50 años se pronunciaban a favor de la "libre expresión", mientras que otro 20 por ciento de ese grupo de edad condicionaba esa libertad a la protección de los menores. ${ }^{45}$ Otra encuesta, desarrollada con anterioridad pero cuyos resultados se dieron a conocer también a comienzos de 1984, mostraba guarismos parecidos. Realizada por la firma Burke a 400 porteños mayores de edad, esta encuesta preguntaba -entre otras cosas- por la aceptación de los desnudos en las artes expresivas y los espectáculos: 45 por ciento del total se manifestaba por poner fin a toda forma de censura, mientras que un 18 por ciento se proclamaba también en ese sentido, aunque reclamaba controles por edad. ${ }^{46}$ Avanzado ya 1984 , El porteño dio a conocer una encuesta propia, en la cual se preguntaba a habitantes del área metropolitana de entre 20 y 40 años, en primer lugar, si consideraban que hubiera un "destape" -entendido, en este caso, por si notaban que había "mayor liberalidad sexual en los ámbitos que frecuentan"- y el 70 por ciento de los varones y el 90 por ciento de las mujeres respondieron afirmativamente. En segundo lugar, un 54 por ciento de los varones y un 40 por ciento de las mujeres consideraron que "el destape es positivo". ${ }^{47}$ Como todas, se trataba de encuestas intencionadas -tanto en sus preguntas como en el contexto en el que se publicaban- que intentaban enfatizar lo extendido de unas actitudes "aperturistas".

En términos de políticas públicas, el aperturismo fue más evidente y rápido en lo concerniente a la cinematografía. Carlos Gorostiza, el Secretario de Cultura de la Nación, fue encargado de presentar y dar visibilidad a la nueva legislación que creaba una Comisión Asesora de Calificación. Esa Comisión se proponía solo calificar de acuerdo a los regímenes de edad. Desde 1984 en adelante, hubieron solo dos filmes extranjeros cuya exhibición se imposibilitó: Yo te saludo, María (Jean-Luc Godard, 1985) y La última tentación de Cristo (Martin Scorsese, 1988). Ambos tocaban temas clave para la Iglesia Católica, cuyos voceros hicieron lobby para impedir su exhibición. Lo mismo sucedió con el filme nacional Kindergarten (Jorge Polaco, 1989) (Sala, 2016). Esos casos hablan tanto de la capacidad de injerencia de los círculos católicos más conservadores en la toma de decisiones, como de sus propios límites en un contexto aperturista. Mucho más, ya desde su asunción Gorostiza advertía que quedaba la puerta abierta para que, a escala municipal o provincial, se definieran las condiciones de exhibición de cine pornográfico - lo cual le valió la reacción inmediata del mundo católico más conservador-..48

La cuestión de la autorización de exhibición y circulación de películas tildadas de pornográficas puso a prueba los límites del aperturismo oficial, algo especialmente evidente en la Ciudad de Buenos Aires. Por un lado, a fines de 1984, por decreto, se modificaron aspectos de la Ley 23.052, introduciéndose por primera vez especificaciones sobre las películas "solo aptas para mayores de 18 , de exhibición condicionada". 
Los distribuidores que solicitaran un certificado a la Comisión Asesora de Calificación pagarían cinco veces más que para las películas no condicionadas. Y, lo más importante, el decreto especificaba que las autoridades municipales eran las encargadas de autorizar la apertura de salas..$^{49}$ Como había sucedido también en la década de 1960, cuando las autoridades porteñas se mostraron más conservadoras que en otros distritos respecto a cuestiones de "costumbres", en la Ciudad de Buenos Aires se empantanó la decisión -mientras que en algunas provincias, como Tucumán, el lobby de dueños de salas de cine fue mayor y lograron reconvertir muchas salas a condicionadas-. En Buenos Aires, en 1984 la bancada legislativa de la Unión Cívica Radical atinó a presentar un proyecto de reglamentación de salas condicionadas, pero-según indicaba un informe- lo retiró por temor a incrementar el enfrentamiento con la Iglesia Católica. ${ }^{50}$

La dilación de la decisión municipal fue, en la Ciudad de Buenos Aires, el modo por el cual se puso límites al aperturismo en lo referente a la exhibición de cine pornográfico. Eso no obturó que diversos empresarios del entretenimiento avanzaran en reconvertir salas para la proyección de condicionadas o, en algunos casos, de películas "eróticas" -prohibidas para mayores de 18, con reservas, en la jerga legal-iniciando pedidos de autorizaciones. Uno de esos empresarios era Jaime Schvarzman Rotbar, también conocido como el "businessman del sexo". Con una larga trayectoria en la distribución de películas eróticas, primero en Brasil y luego en la Argentina, Schvarzman Rotbar era propietario del complejo Multicine, en la calle Lavalle -que se especializaba en la proyección de "eróticos"- y compró el viejo cine Ideal con la intención de convertirlo en el centro de la exhibición de condicionados ${ }^{51}$ La programación de esas salas -y de otras que fueron integrándose al circuito "erótico"- era provista por films distribuidos por tres empresas, Lucian, Vanguardia Hot y Hardcore, que importaban una mayoría de sus películas desde Estados Unidos, y menos desde Francia y Brasil. Un informe indicaba que, en 1985, se habían vendido 865 mil entradas para ver películas "eróticas" o "porno"-alrededor del 10 por ciento del total de las entradas vendidas en la Ciudad de Buenos Aires-..$^{52}$ No extraña, así, que otros empresarios se fueran animando a abrir salas. Para 1987 se habían sumado otras seis, usualmente cerca de las estaciones de trenes (dos en Retiro, una en Constitución, otra en Once, dos más en Barrio Norte) que funcionaban de manera continuada aunque perviviera el temor a la arbitrariedad de los cierres repentinos, o las multas (el cine Ideal, por ejemplo, tuvo al menos 35 multas en tres meses). ${ }^{53}$ Fue recién en 1988 cuando la Municipalidad de Buenos Aires reglamentó el funcionamiento de esas salas, una reglamentación difícil de cumplir: debían tener un mínimo de 150 butacas; estar localizadas a no menos de 150 metros de escuelas, templos y otras salas de espectáculos; y proyectar solo filmes en 35 milímetros-cuando lo usual eran filmes en 16 milímetros-. Inconsultos, los propietarios de las salas de exhibición condicionada de Buenos Aires siguieron en la ilegalidad..$^{54}$

Como sucedió con otros aspectos del "destape", las derivas de la distribución, exhibición y consumo del cine pornográfico recorrieron otros carriles ligados a las transformaciones de la cultura de masas en general, y de la audiovisual en particular. El canal privilegiado para la diseminación del cine pornográfico fue el video, una tecnología que fue impregnando la cotidianeidad de millones de personas precisamente desde la década de 1980, cuando se expandió exponencialmente la venta de videocaseteras. A mediados de la década, las tres grandes distribuidoras de películas pornográficas habían importado 250 títulos, cuya distribución se hacía en albergues transitorios y en los, por el momento, escasos videoclubes habilitados. En el bienio 1986 y 1987 se sumaron dos nuevas distribuidoras, que apuntaban a nichos específicos de mercado, en particular mediante el llamado "porno gay".55 $\mathrm{Al}$ finalizar la década, la expansión había sido ciertamente exponencial. En 1988, se contabilizaban 500 mil videocaseteras vendidas (muchas de ellas, ya, para hogares) y se encontraban
49. "Cinematografía: Decreto 3899”, Boletín oficial, 21 de diciembre de 1984,7 .

50. “Cine porno: una polémica que recién empieza", Clarín, 27 de junio de 1984, 28-9.

51.“Una realidad de todos los países modernos", Clarín, 27 de junio de 1984, 28; Aníbal Vineli, "Cine porno", Humor n⿳0 163, noviembre de 1985, 70-1.

52. Silvia Itkin, "El negocio del destape", Humor no 166 , enero de 1986, 66-69.

53. "La penuria del cine chancho", Humor no 200 , Julio de 1987, 73-5; Hugo Peredero, "Otra historia de sexo", Humor no 206, octubre de $1987,63-5$.

54. "Cine en libertad condicionada", El periodista de Buenos Aires $\mathrm{n}{ }^{\circ} 194,10$ de junio de 1988, 54-6.

55. Marcelo Figueras, “Video, porno show”, Humor nำ193, marzo de 1987, 64-7. 
56. Aníbal Vinelli “La censura no entra al living", Humor no 222 , junio de 1988, 75 ; Víctor Pintos, "Solo una mala postura", Humor no. 238 , marzo de $1989,42-3$.
57. Eduardo Blaustein, "Del destape al desencanto, del pasotismo a la vida", Tiempo Argentino, 9 de diciembre de 1983, Suplemento “Tiempo Joven”, 2. habilitados 2000 videoclubes, una mayoría en el área metropolitana de Buenos Aires. $\mathrm{Al}$ año siguiente, un informe mostraba que los títulos de películas pornográficas que habían obtenido certificados de distribución ascendían a 1100, en su mayoría localizables en videoclubes. Como lo remarcaba con cierto optimismo el crítico de espectáculos Aníbal Vinelli, tamaña expansión del video podía tener un efecto democratizador (él pensaba en el acceso amplio a una variedad de géneros y repertorios de todos los tiempos) y, sobre todo, anti-represivo: "la censura", concluía, "no entra al living". .56

El ejemplo del cine pornográfico ofrece una ventana para revisar, entonces, algunas dinámicas del entrecruzamiento entre sexo, cultura de masas y política en la década de 1980 . Se trataba de una industria -o un género- en expansión a escala transnacional desde la década de 1970 y su llegada a la Argentina estuvo contenida por las disposiciones restrictivas que regían para la producción, distribución y exhibición de películas. Como sucediera también en España, la llegada de estas películas al escenario doméstico tuvo lugar en un contexto transicional, por lo cual la puesta al día de la cultura sexual argentina -como sucediera con la española- asumió, desde lo retórico y lo político, la categoría de "destape". Mientras que desde las políticas oficiales se oscilaba entre el aperturismo y el cercenamiento, las transformaciones de la cultura sexual seguían su vida propia, en buena medida porque se imbricaron con transformaciones más profundas en la cultura de masas y en la disposición de medios de reproductibilidad que hacían más difícil el control y el monitoreo estatal sobre qué, cuándo y cómo las personas podían consumir, por ejemplo, películas pornográficas.

\section{Conclusiones}

En diciembre de 1983, en una crónica sobre las transformaciones de las culturas juveniles en España, el por entonces muy joven periodista Eduardo Blaustein -exiliado en Barcelona desde 1977 y retornado poco antes de la asunción de Alfonsín- reconstruía las dinámicas más importantes en el mundo de las publicaciones, la música y también las sexualidades juveniles. Como muchos colegas antes y después que él, Blaustein no pudo evitar la comparación entre sus rememoraciones del "destape" español y lo que veía como un emergente "destape" argentino: "hay una intima conexión," escribía, "entre democracia y destape", pero a la hora de reflexionar sobre el posible impacto y alcance en un país y el otro, sugería a sus lectores "dividir cuarenta por siete" ${ }^{57}$ Los cuarenta, por supuesto, eran los años que duró la dictadura franquista $y$, los siete, la dictadura argentina. La interpretación contenía una hipótesis adicional: que a mayor tiempo e intensidad de represión, mayor sería el alcance del "destape". Se trata de una interpretación que recorrió muchas de las intervenciones que tomaban al "destape" español como unidad de referencia para medir las dinámicas que se daban en la Argentina. Más fundamentalmente, se enmarcaba en un sustrato interpretativo que abonaba la hipótesis del efecto reacción: a mayor intensidad y perdurabilidad de la represión, mayores los alcances del "destape". Esa interpretación de época colaboraba con el establecimiento de una frontera imaginaria entre dictadura/ represión y democracia/libertad, o "destape". Dejaba de lado la posibilidad de hacer visibles las muchas continuidades entre la cultura sexual de la década de 1960 y la dictadura, y entre esta y la "transicional". Este último contexto marcó una puesta al día de algunas dimensiones de una cultura sexual, en lo fundamental aquellas que, en su contexto, eran tildadas de pornográficas, ya sea en materiales impresos como audiovisuales.

El debate público en torno al "destape" cristalizó, en lo sustancial, en torno a qué hacer, o cómo tolerar, eso denominado pornográfico, un debate que sirvió de vehículo 
para esclarecer posiciones respecto a la censura en un contexto que, desde diciembre de 1983 , se auto-representaba como aperturista. Las posiciones básicas fueron tres. En primer lugar, desde los segmentos más conservadores de la Iglesia Católica se insistía en la necesidad de contener el "permisivismo" y defender el "derecho al pudor", posiciones que se hicieron más militantes y extremas desde la asunción del gobierno de Alfonsín. Teniendo una indudable capacidad de lobby, no se trataba de la posición hegemónica. Tampoco lo era una segunda posición, asumida por algunos periodistas ligados al mundo contracultural -como Enrique Symns- que daban la bienvenida al "destape" en general, y a la pornografía en particular. Posiblemente una tercera variante fue mucho más extendida: hacía una defensa de la libertad de expresión (y una oposición abierta a la censura) mientras, en algunos casos, cuestionaba al "destape" en función de diferentes variables y discursos - de género; de crítica a la cultura de masas y sus gustos "chabacanos"-. El oficialismo pivoteó entre la primera y la tercera de las posiciones. En sintonía con su pretensión aperturista, existió una voluntad política de reasegurar la libertad de expresión y el fin de la censura pero, a la vez, utilizó una serie de estrategias para morigerar al "destape" -permitir una intensa oleada de judicialización en el caso de las revistas, dilatar decisiones y reglamentaciones en el caso de las películas, o directamente autorizar razzias contra segmentos concebidos como problemáticos-.

Fue, sin embargo, por esa ventana de oportunidades que se abrió con el correr de la década de 1980 cuando terminaron por delinearse rasgos importantes de una dinámica de mediano plazo, la sexualización de la cultura de masas. Se trataba, por supuesto, de una dinámica no circunscripta a lo nacional, sino que tanto sus materiales, rasgos y estéticas reconocen viajes y préstamos transnacionales. Fue la discusión política, el qué se dijo cuando se habló de sexo, aquello que "localizó" a ese proceso, y esa discusión nos habla a la vez de la historia de la sexualidad y de la historia política. En la historia de la sexualidad, nos informa de una actualización de la cultura sexual argentina, una que retomaba rasgos ya insinuados en la década de 1960 y solo parcialmente eclipsados en los momentos más álgidos de aplicación de la censura dictatorial. La salida de la dictadura argentina no era, por supuesto, la salida del franquismo, pero para muchos actores la interpretación era similar: apertura política significaba apertura cultural y sexual. El término "destape" le puso un nombre a esa interrelación. Mirado desde la perspectiva de la historia política, el "destape" nos muestra que los límites del aperturismo fueron, en la Argentina de la transición, muy rápidamente alcanzados. 


\section{Q Bibliografía}

»Aboy Carlés, Gerardo (2001). Las dos fronteras de la democracia argentina, Rosario, Argentina: Homo Sapiens.

"Blázquez, Gustavo y María G. Lugones (2014). 'Cositas fuera de lugar': miradas oblicuas en y sobre una noche cordobesa de inicios de los 8o. En Dora Barrancos, Donna Guy y Adriana Valobra (Eds.), Moralidades y comportamientos sexuales: Argentina, 1880-2011. Buenos Aires, Argentina: Biblos.

» Bronstein, Carolyn y Whitney Strub (Eds.) (2016). Porno Chic and the Sex Wars: American Sexual Representation in the 1970., Amherst, Estados Unidos: University of Massachusetts Press.

"Cáceres García, Juli (2008). El destape del macho ibérico: masculinidades disidentes en la comedia sexy (celt) ibérica (Tesis doctoral). Georgetown University, Washington DC, Estados Unidos.

»Clark, Anne (2008). Desire: A History of European Sexuality. Nueva York, Estados Unidos: Routledge.

"Cosse, Isabella (2010). Pareja, sexualidad y familia en los años sesenta: una revolución discreta en Buenos Aires. Buenos Aires, Argentina: Siglo XXI.

»D’Antonio, Débora (2015). Las sexy comedias en la filmografía argentina durante los años de la última dictadura militar: una lectura sobre el control y la censura. En Débora D’Antonio (Coord.), Deseo y represión: sexualidad, género y Estado en la historia argentina reciente. Buenos Aires, Argentina: Imago Mundi.

» D'Emilio, John y Freedman, Estelle (1997). Intimate Matters: A History of Sexuality in Modern America. Chicago, Estados Unidos: University of Chicago Press.

»Eidelman, Ariel (2015). Moral católica y censura municipal de las revistas eróticas en la ciudad de Buenos Aires en la década del sesenta. En D’Antonio (Comp.), Deseo y represión. Buenos Aires, Argentina: Imago Mundi.

»Ekerman, Maximiliano (2014). Luz, cámara y control: la industria cinematográfica argentina durante la última dictadura militar (1976-1983). (Tesis de maestría en Historia Contemporánea). Universidad Nacional de General Sarmiento. Buenos Aires, Argentina.

» Fabris, Mariano (2012). El Episcopado argentino, el „destape“ y la amenaza a los valores tradicionales, 1981-1985. Revista Cultura y Religión, vol. VI (no 1).

»Feld, Claudia (2015). La prensa de la transición ante el problema de los desaparecidos: el discurso del "show del horror". En Marina Franco y Claudia Feld, (coord.), Democracia, hora cero: actores, políticas y debates en los inicios de la postdictadura. Buenos Aires, Argentina: Fondo de Cultura Económica.

»Felitti, Karina (2012). La revolución de la pilldora: sexualidad y política en los sesenta. Buenos Aires, Argentina: Edhasa.

"Franco, Marina (2017). La "transición" argentina como objeto historiográfico y como problema histórico. Ayer, vol. 107 (nํ․ 3), 125-152.

»Gargarella, Roberto (2010). Democracia y derechos en los años de Raúl Alfonsín. En Roberto Gargarella, María Victoria Murillo y Mario Pecheny (Eds.), Discutir Alfonsín. Buenos Aires, Argentina: Siglo XXI. 
"Garrote, Valeria (2013). La estrategia de la alegría en los colectivos artísticos de la dictadura y post-dictadura en España y Argentina (1973-1989) (Tesis doctoral). Rutgers University, New Jersey, Estados Unidos.

" Herzog, Dagmar (2005). Sex after Fascism: Memory and Morality in Twentieth Century Germany. Princeton, NJ., Estados Unidos: Princeton University Press.

" López Perea, Fedra (2017). "Represión estatal contra las sexualidades no heteronormativas en la apertura democrática, 1983-1986", ponencia presentada en las III Jornadas de Trabajo de la Red de Estudios sobre Represión y Violencia Política, Universidad Nacional de La Plata.

»Lucena, Daniela y Laboureau, Gisela (2016). Modo mata moda: arte, cuerpo y (micro) política en los 8o. La Plata, Argentina: Editorial de la Universidad de La Plata.

» Manzano, Valeria (2015). Sex, Gender, and the Making of the 'Enemy Within' in Cold War Argentina. Journal of Latin American Studies, vol. 47 ( $n \div .2$ ).

»Manzano, Valeria (2014). The Age of Youth in Argentina: Culture, Politics, and Sexuality from Perón to Videla, Chapel Hill, Estados Unidos: University of North Carolina Press.

»Manzano, Valeria (2005). Sexualizing Youth: Morality Campaigns and Representations of Youth in Early-1960s Buenos Aires. Journal of the History of Sexuality, vol. 14 ( $\left.n^{\circ} .4\right)$.

» Monterde, José Enrique (1993). Veinte años de cine español (1973-82). Un cine bajo la paradoja. Barcelona: Paidós, 1993.

»Ponce, José María (2004). El gran destape nacional: crónica del desnudo en la Transición. Barcelona, España: Glénar.

"Quaggia, Giulia (2014). La cultura en transición: reconciliación y política cultural en España, 1976-1986, Madrid, España: Alianza.

"Ramírez Llorens, Fernando (2016). Noches de sano esparcimiento: estado, católicos y empresarios en la censura al cine en la Argentina (1955-1973). Buenos Aires, Argentina: Libraria/ENERC.

»Sala, Jorge (2016). Crónica de un caso de censura: Kindergarten (Jorge Polaco, 1989), la iglesia y la frágil postdictadura argentina. Atrio, $n \stackrel{0}{22}$.

"Sempol, Diego (2013). Violence and the Emergence of Gay and Lesbian Activism in Argentina, 1983-1990. En Saskia Wieringa y Horacio Sivori (Eds.), The Sexual History of the Global South. Londres, Inglaterra: Zed Books.

»Trastoy, Beatriz (2003). Teatro Abierto 1981: un fenómeno social y cultural. En Osvaldo Pelletieri (Ed.), Historia del teatro argentino, 1976-1998. Buenos Aires, Argentina: Galerna.

»Usubiaga, Viviana (2012). Artes visuales, dictadura y democracia en Buenos Aires. Buenos Aires, Argentina: Edhasa. 
